\title{
Comparison Between the New Bodies of Knowledge for the Civil Engineering Professional and the Civil Engineering Technologist
}

\author{
Prof. Horst Brandes P.E., University of Hawaii \\ Professor of Geotechnical Engineering, University of Hawaii
}

\section{Dr. Joe D. Manous Jr, U.S. Army Corps of Engineers}

Joe Manous serves as a Water Resources Engineer and the Manager for International Activities at the Institute for Water Resources, US Army Corps of Engineers. Dr Manous specializing in the areas of water resources and environmental security issues associated with water. He also works closely with the Office of the Assistant Secretary of the Army for Civil Works and is an Adjunct Professor at George Mason University teaching courses in engineering economics and water resources. Dr Manous is a former US Army Corps of Engineers officer, retiring from active duty in the grade of Colonel. His last active duty assignment was as Academy Professor at the United States Military Academy at West Point, where he taught courses in environmental engineering, water resources, and environmental security.

\section{Dr. Kenneth J. Fridley, University of Alabama}

Kenneth J. Fridley is the Senior Associate Dean for the College of Engineering at The University of Alabama. Prior to his current appointment, Fridley served as Professor and Head of the Department of Civil, Construction and Environmental Engineering at the University of Alabama. Dr. Fridley has been recognized as a dedicated educator throughout his career and has received several awards for his teaching efforts, including the ExCEEd (Excellence in Civil Engineering Education) Leadership Award in 2010. At the University of Alabama, Fridley has led efforts to establish several new programs including new undergraduate degree programs in construction engineering, architectural engineering and environmental engineering, a departmental Scholars program allowing highly qualified students an accelerated program to earn their MSCE in addition to their BS degree, the interdisciplinary "Cube" promoting innovation in engineering, and the cross-disciplinary MSCE/MBA and MSCE/JD dual-degree programs. 


\section{Comparison Between the New Bodies of Knowledge for the Civil Engineering Professional and the Civil Engineering Technologist}

\section{Background}

Civil engineering relies on a strong formal knowledge and skills base acquired largely through higher education and experience. Central to the identity of civil engineering as a profession is the need for such expert knowledge and skills, independence of thought and judgment, and an ethos to serve the public good grounded in a sound code of ethics [1], [2]. The American Society of Civil Engineers (ASCE) formally endorsed the attainment of a civil engineering body of knowledge for entry into the practice of civil engineering in its Policy Statement 465 [3], first adopted in 1998. The initial edition of this body of knowledge (CE-BOK1) was published in 2004 and defined the knowledge, skills, and attitudes (KSA) required of an individual entering the practice of civil engineering at the professional level. At the time, it was considered a groundbreaking document and it received considerable attention and praise.

While a body of knowledge is essential to the idea of professionalism, it can quickly become obsolete in the face of changes in knowledge, technology and the marketplace of professions. In order to remain effective, and for the profession to stake firm jurisdictional claims, such a document must be updated on a regular basis [4], [5], [6]. ASCE published the second version of the body of knowledge in 2008 (CE-BOK2) and now is in the final stages of preparing the third version (CE-BOK3), which is scheduled to be published in the spring of 2019. Current plans call for the CE-BOK to be revisited every eight years.

Civil engineering work has evolved to encompass the distinctive and complementary roles of not only engineering professionals, but also technologists and technicians. Such segmentation is not unlike that encountered in other learned professions, such as medicine or law, and it is critical to the efficiency and success of the civil engineering workforce. ASCE, through Policy Statement 535 [7], views the core of the civil engineering team as consisting not only of the Civil Engineering Professional, but also the Civil Engineering Technologist and the Civil Engineering Technician. Currently, the Committee on the Civil Engineering Technologist is tasked with furthering the prospects of individuals who engage in specialized technology work. As part of these efforts, a task committee was formed in 2015 to develop the first version of a Body of Knowledge for Civil Engineering Technologists (CET-BOK) to serve a similar function to the CE-BOK for Civil Engineering Professionals. The CET-BOK was completed in 2017[8].

By spring 2019, both bodies of knowledge will be available for general reference. The three authors of this paper have been involved in the development of one or both of these documents. Although similar in intent and based on equivalent Bloom's taxonomies for their construct, there are significant differences between the two that reflect variations in knowledge base and skills, but also somewhat contrasting visions and overall work approaches by the two groups. It should be stated that with the exception of the first author, there was no overlap in the composition of the two committees and relatively limited interaction. The purpose here is to provide a brief overview of the outcomes for each body of knowledge and to compare and contrast how both 
efforts have progressed with recommendations provided for a unified process when it comes time to update the two bodies again. This information may be of interest to engineers, technologists, and the ASCE leadership tasked with implementing these efforts into the future.

Given civil engineering's heavy reliance on specialized knowledge and skills, an emphasis on taxonomy to delineate the profession is deemed especially relevant. Within the sociology of professions, this approach has received significant criticism precisely because of its heavy reliance on knowledge and expertise while neglecting other important traits such as interactionism, ideology, purpose, and political context, which are relevant for certain professions and occupations [9] - [12]. The empirical nature inherent in compiling a body of knowledge, no matter how deliberate and carefully crafted, represents a further limitation that must be recognized. While deemphasizing the centrality of knowledge and expertise to defining a profession has been at the center of more recent approaches to defining a profession, such as the neo-Weberian approach (see for example [13], [14]), these concepts are not considered as useful in the case of civil engineering because of the profession's grounding in a very specialized body of knowledge and skills.

Bloom's taxonomy [15] provides a straightforward framework for defining levels of achievement that can be associated with specific knowledge and skills outcomes. While considered obsolete by many, Bloom's taxonomy is well known and widely documented in the literature, including the engineering field. Bloom's emphasis on action-oriented verbs allows for crafting of specific knowledge and skills outcomes, in terms of hierarchical levels of achievements, which can be assessed consistently and effectively. Bloom's taxonomy identifies three distinct domains: the cognitive domain, which emphasizes the recognition, recall and processing of cognitive knowledge; the affective domain, which relates to the way in which individuals react emotionally; and the psychomotor domain, which describes physical ability to manipulate a tool or an instrument. A revised Bloom's taxonomy was proposed more recently [16] with a somewhat more dynamic concept of classification. After research and deliberation, both civil engineering bodies of knowledge decided to stick with the original Bloom's taxonomy for reasons of continuity, effectiveness and compatibility.

\section{The body of knowledge for civil engineering professionals (CE-BOK3)}

In October 2016, ASCE launched the Body of Knowledge 3 Task Committee (CE-BOK3) and charged the task committee to critically review published literature regarding the future of engineering, other disciplines and civil engineering practice; proactively solicit constituent input; evaluate the CE-BOK2; determine if a third edition of the Civil Engineering Body of Knowledge report is warranted; and, if warranted, develop the CE-BOK3 report. To fulfill their charge, the committee employed a five-phase process.

The first phase focused on reviewing available literature, conducting a survey of constituents, and determining whether a third edition of the CE-BOK was needed. This first phase was fully reported in a paper presented at the 2017 ASEE Annual Conference \& Exposition[17]. Through the critical review of the literature, the consensus of the BOK3 
task committee was that revisions to the BOK2 were appropriate and justified, and that the committee would move forward and develop a third edition of the CE-BOK.

The second and third phases of the BOK3 task committee's work are being presented at the 2018 ASEE Annual Conference \& Exposition [18]. The second phase involved developing possible new outcomes and revising existing CE-BOK2 outcomes based on information from the first phase, conducting an internal survey of all BOK 3 task committee members (full and corresponding), and developing pre-draft outcome rubrics for the CE-BOK3. The third phase focused on critically assessing the pre-draft CE-BOK3 outcome rubrics, including conducting a second formal survey of constituents, to develop the first draft of the CE-BOK3 outcomes. This first draft includes the outcome rubrics, level of achievement expected for each outcome, and a typical pathway to fulfill the outcome. As with previous editions of the CE-BOK, the pathway to fulfillment includes both formal education, both at the undergraduate (UG) and post-graduate (PG) levels, and mentored experience (ME).

As noted previously, the CE-BOK2 [19] adopted Bloom's Taxonomy for the cognitive domain, but acknowledged "several outcomes ... would be enhanced by descriptions in ... affective domain." The affective domain describes emotional or character development and defines the manner in which individuals deal with interests, values, appreciation, enthusiasm, motivation, and attitudes. The BOK3 task committee decided the CE-BOK3 would continue to use Bloom's taxonomy for the cognitive domain and add Bloom's taxonomy for the affective domain for an appropriate subset of outcomes. With the introduction of the affective domain, the BOK3 task committee also proposed to introduce another possible mechanism for fulfilling outcomes. In addition to UG, PG, and $\mathrm{ME}$, self-development (SD) is considered as part of the typical pathway to fulfillment of the affective domain outcomes. Table 1a provides a summary of the 21 outcomes that comprise the CE-BOK 3 in the cognitive domain, and Table $1 \mathrm{~b}$ includes a summary of the seven outcomes that are also defined in the affective domain. Both tables also include the typical pathway to fulfillment.

Phase four involves the development of explanations for each of the outcomes and seeking a final round of input from constituency groups on the CE-BOK3 outcomes and explanations. The final phase will include a full evaluation of all constituency input resulting from phase four, and the development of the final draft of the CE-BOK3 report. It is expected that the final CE-BOK3 report will be published in early 2019. 
Table 1a. Preliminary Cognitive Outcomes for CE-BOK3

\begin{tabular}{|c|c|c|c|c|c|c|}
\hline Outcome & $\begin{array}{c}\text { Level } 1 \\
\text { Remember } \\
\end{array}$ & $\begin{array}{c}\text { Level } 2 \\
\text { Comprehend } \\
\end{array}$ & $\begin{array}{l}\text { Level } 3 \\
\text { Apply } \\
\end{array}$ & $\begin{array}{r}\text { Level } 4 \\
\text { Analyze } \\
\end{array}$ & $\begin{array}{c}\text { Level } 5 \\
\text { Synthesize } \\
\end{array}$ & $\begin{array}{r}\text { Level } 6 \\
\text { Evaluate } \\
\end{array}$ \\
\hline 1. Mathematics & UG & UG & UG & PG & & \\
\hline 2. Natural Sciences & UG & UG & UG & PG & & \\
\hline 3. Social Sciences & UG & UG & UG & & & \\
\hline 4. Humanities & UG & UG & UG & & & \\
\hline 5. Materials Science & UG & UG & UG & & & \\
\hline $\begin{array}{ll}\text { 6. } & \text { Engineering } \\
& \text { Mechanics } \\
\end{array}$ & UG & UG & UG & UG & & \\
\hline $\begin{array}{l}\text { Exper. Methods } \\
\text { and Data Analysis }\end{array}$ & UG & UG & UG & PG & & \\
\hline $\begin{array}{l}\text { 8. Critical Thinking } \\
\text { \& Problem Solving }\end{array}$ & UG & UG & UG & ME & $\mathrm{ME}$ & \\
\hline $\begin{array}{ll}\text { 9. } & \text { Project } \\
& \text { Management }\end{array}$ & UG & UG & UG & $\mathrm{ME}$ & & \\
\hline $\begin{array}{l}\text { 10. Engineering } \\
\text { Economics }\end{array}$ & UG & UG & ME & & & \\
\hline $\begin{array}{l}\text { 11. Risk and } \\
\text { Uncertainty }\end{array}$ & UG & UG & UG & ME & & \\
\hline $\begin{array}{l}\text { 12. Breath in Civil } \\
\text { Engineering Areas }\end{array}$ & UG & UG & UG & ME & & \\
\hline 13. Design & UG & UG & UG & ME & ME & \\
\hline 14. Technical Depth & UG & UG & PG & PG & $\mathrm{ME}$ & \\
\hline 15. Sustainability & UG & UG & UG & $\mathrm{ME}$ & & \\
\hline 16. Communication & UG & UG & UG & $\mathrm{ME}$ & $\mathrm{ME}$ & \\
\hline $\begin{array}{l}\text { 17. Teamwork and } \\
\text { Leadership }\end{array}$ & UG & UG & UG & ME & ME & \\
\hline 18. Lifelong Learning & UG & UG & UG & ME & $\mathrm{ME}$ & \\
\hline $\begin{array}{l}\text { 19. Professional } \\
\text { Attitudes }\end{array}$ & UG & UG & $\mathrm{ME}$ & $\mathrm{ME}$ & & \\
\hline $\begin{array}{l}\text { 20. Professional } \\
\text { Responsibilities }\end{array}$ & UG & UG & $\mathrm{ME}$ & $\mathrm{ME}$ & $\mathrm{ME}$ & \\
\hline $\begin{array}{l}\text { 21. Ethical } \\
\text { Responsibilities }\end{array}$ & UG & UG & ME & $\mathrm{ME}$ & $\mathrm{ME}$ & \\
\hline
\end{tabular}


Table 1b. Preliminary Affective Outcomes for CE-BOK3

\begin{tabular}{|c|c|c|c|c|c|}
\hline Outcome & $\begin{array}{l}\text { Level } 1 \\
\text { Receive }\end{array}$ & $\begin{array}{c}\text { Level } 2 \\
\text { Respond }\end{array}$ & $\begin{array}{c}\text { Level } 3 \\
\text { Value }\end{array}$ & $\begin{array}{c}\text { Level } 4 \\
\text { Organize }\end{array}$ & $\begin{array}{c}\text { Level } 5 \\
\text { Characterize }\end{array}$ \\
\hline 15. Sustainability & UG & UG & ME & SD & \\
\hline 16. Communication & UG & UG & ME & SD & \\
\hline $\begin{array}{l}\text { 17. Teamwork and } \\
\text { Leadership }\end{array}$ & UG & UG & ME & SD & \\
\hline 18. Lifelong Learning & UG & UG & ME & SD & \\
\hline $\begin{array}{l}\text { 19. Professional } \\
\text { Attitudes }\end{array}$ & UG & UG & ME & SD & \\
\hline $\begin{array}{l}\text { 20. Professional } \\
\text { Responsibilities }\end{array}$ & UG & UG & ME & SD & \\
\hline $\begin{array}{l}\text { 21. Ethical } \\
\text { Responsibilities }\end{array}$ & UG & UG & ME & $\mathrm{ME}$ & SD \\
\hline
\end{tabular}

\section{The body of knowledge for civil engineering technologists (CET-BOK)}

Civil Engineering Technologists have always been members of the civil engineering profession, even if they are not identified as such. Many state agencies have developed job classifications that specify levels of education and experience that closely reflect those of a Civil Engineering Technologist. The same is true for the federal government and some large private firms. Civil Engineering Technologists are often identified by their area of practice and expertise. For example, a Transportation Technologist at a Department of Transportation may oversee field surveying, preparation of right of way plans, inspection of paving operations, or testing construction materials. A Geotechnical Technologist for a private firm may be responsible for supervising field soil borings or pile installations, or perhaps be in charge of laboratory equipment and testing of soil or rock specimens.

As with any other learned occupation, the effectiveness of a Civil Engineering Technologist is tied directly to experience. In the truest sense, a Civil Engineering Technologist should be viewed as an individual who has acquired a high level of knowledge and skill in their chosen area of specialty and has practiced in that field for a significant amount of time. An individual who chooses to work as a Civil Engineering Technologist as a long-term occupation has the potential to add significant value to the workforce and merits recognition by virtue of fulfilling an in-depth body of knowledge.

It is noted that the term Civil Engineering Technologist does not appeal to everyone and other terms such as Associate Engineer, Paraprofessional, Practitioner, and others have been suggested and are used in various workplace settings. In general, these designations are poorly defined and do not correlate well with international usage or other learned professions and therefore are prone to be misunderstood. Herein the Civil Engineering Technologist is defined through its own body of knowledge, which implicitly recognizes his or her valuable contributions to the civil engineering enterprise. 
The most significant challenge encountered in developing a CET-BOK was how to describe it without reference to a well-defined educational path or accepted milestones, such as a standardized examination or credential. Each of these criteria are standard practice for identifying Civil Engineering Professionals, but for reasons discussed below do not apply equally to Civil Engineering Technologists. In addition, it was determined that while Civil Engineering Technologists exercise significant skill and judgment in their roles and they can follow a very wide range of potential career pathways. This further complicates development of a single body of knowledge for the Civil Engineering Technologist.

The CET-BOK presumes a combination of formal education and supervised work experience in one or more technology fields. The structure of the CET-BOK is similar to the CE-BOK to provide familiarity in approach and facilitate an understanding of similarities and differences between Civil Engineering Technologists and Civil Engineers.

However, an area of presumed similarity between Civil Engineering Professionals and Civil Engineering Technologists, ABET accreditation, was not found to be a consistent indicator of educational content. The outcomes for academic programs accredited under the Engineering Technology Accreditation Commission (ETAC) of various two and four-year programs vary widely and the career paths for some programs can lead directly to professional licensure rather than a career as a Civil Engineering Technologist. At the same time, other engineering graduates find successful careers working in areas described as Civil Engineering Technologists as defined by ASCE Policy Statement 535. As such, no single formal college degree program was identified that could be associated with Civil Engineering Technologists the way the B.S. is associated with Civil Engineering Professionals, but several alternatives were identified as viable options. This conclusion may complicate the issuance of a future Civil Engineering Technologist credential, but highlights the need for a common knowledge standard or CETBOK.

The CET-BOK includes 16 main or foundational cognitive outcomes (see Table 2a for outcome titles) as compared to 21 similar outcomes in the CE-BOK (Table 1a). These foundational outcomes serve a similar function as those in the CE-BOK, as they describe knowledge and skills that apply to all Civil Engineering Technologists, regardless of their individual specialty area or type of workplace.

In a significant departure from the CE-BOK for Civil Engineering Professionals, the CET-BOK also includes 17 Technologist Specialty Outcomes (Table 2b). While these outcomes might be considered imbedded components of the CE-BOK, they are uniquely identified in the CET-BOK as areas of specialization and in-depth skill that define a Civil Engineering Technologist's abilities and accomplishments. A similar level of specialized technologist mastery is not explicitly required in the CE-BOK. A Civil Engineering Technologist must demonstrate mastery of at least one of the Technologist Specialty Outcomes, but could chose to demonstrate mastery in one or more. 
Table 2a. Cognitive Foundational Outcomes for CET-BOK

\begin{tabular}{|c|c|c|c|c|c|c|}
\hline Outcome & $\begin{array}{c}\text { Level } 1 \\
\text { Know } \\
\end{array}$ & $\begin{array}{c}\text { Level } 2 \\
\text { Comprehend } \\
\end{array}$ & $\begin{array}{c}\text { Level } 3 \\
\text { Apply } \\
\end{array}$ & $\begin{array}{c}\text { Level } 4 \\
\text { Analyze } \\
\end{array}$ & $\begin{array}{c}\text { Level } 5 \\
\text { Synthesize } \\
\end{array}$ & $\begin{array}{r}\text { Level } 6 \\
\text { Evaluate } \\
\end{array}$ \\
\hline 1. Mathematics & $\checkmark$ & $\checkmark$ & $\checkmark$ & & & \\
\hline 2. Natural Sciences & $\checkmark$ & $\checkmark$ & $\checkmark$ & & & \\
\hline 3. Humanities & $\checkmark$ & $\checkmark$ & & & & \\
\hline 4. Social Sciences & $\checkmark$ & $\checkmark$ & & & & \\
\hline $\begin{array}{l}\text { 5. Civil Engineering } \\
\text { Materials } \\
\end{array}$ & $\checkmark$ & $\checkmark$ & $\checkmark$ & & & \\
\hline 6. Mechanics & $\checkmark$ & $\checkmark$ & $\checkmark$ & & & \\
\hline $\begin{array}{ll}\text { 7. } & \text { Problem } \\
\text { Identification and } \\
\text { Resolution }\end{array}$ & $\checkmark$ & $\checkmark$ & $\checkmark$ & & & \\
\hline 8. Sustainability & $\checkmark$ & $\checkmark$ & $\checkmark$ & & & \\
\hline $\begin{array}{l}\text { 9. Breath in Civil } \\
\text { Engineering }\end{array}$ & $\checkmark$ & $\checkmark$ & & & & \\
\hline 10. Communication & $\checkmark$ & $\checkmark$ & $\checkmark$ & & & \\
\hline 11. Business Acumen & $\checkmark$ & $\checkmark$ & & & & \\
\hline 12. Leadership & $\checkmark$ & $\checkmark$ & $\checkmark$ & & & \\
\hline $\begin{array}{l}\text { 13. Public Policy, } \\
\text { Laws and } \\
\text { Regulations } \\
\end{array}$ & $\checkmark$ & $\checkmark$ & & & & \\
\hline 14. Teamwork & $\checkmark$ & $\checkmark$ & $\checkmark$ & & & \\
\hline $\begin{array}{l}\text { 15. Professional } \\
\text { Growth and } \\
\text { responsibility }\end{array}$ & $\checkmark$ & $\checkmark$ & $\checkmark$ & & & \\
\hline 16. Ethics & $\checkmark$ & $\checkmark$ & $\checkmark$ & $\checkmark$ & & \\
\hline
\end{tabular}


Table 2b. Cognitive Technologist Specialty Outcomes for CET-BOK

\begin{tabular}{|c|c|c|c|c|c|c|}
\hline Outcome & $\begin{array}{l}\text { Level } 1 \\
\text { Know }\end{array}$ & $\begin{array}{c}\text { Level } 2 \\
\text { Comprehend } \\
\end{array}$ & $\begin{array}{l}\text { Level } 3 \\
\text { Apply }\end{array}$ & $\begin{array}{c}\text { Level } 4 \\
\text { Analyze } \\
\end{array}$ & $\begin{array}{c}\text { Level } 5 \\
\text { Synthesize }\end{array}$ & $\begin{array}{c}\text { Level } 6 \\
\text { Evaluate }\end{array}$ \\
\hline $\begin{array}{ll}\text { a. } & \text { Survey and } \\
\text { Geomatics }\end{array}$ & $\checkmark$ & $\checkmark$ & $\checkmark$ & & & \\
\hline $\begin{array}{ll}\text { b. } & \text { Field and } \\
\text { Laboratory Data } \\
\text { Collection } \\
\end{array}$ & $\checkmark$ & $\checkmark$ & $\checkmark$ & & & \\
\hline c. Data Processing & $\checkmark$ & $\checkmark$ & $\checkmark$ & & & \\
\hline d. Drafting Software & $\checkmark$ & $\checkmark$ & $\checkmark$ & & & \\
\hline e. Testing Standards & $\checkmark$ & $\checkmark$ & $\checkmark$ & $\checkmark$ & & \\
\hline $\begin{array}{ll}\text { f. } & \text { Codes and } \\
\text { Standards }\end{array}$ & $\checkmark$ & $\checkmark$ & $\checkmark$ & & & \\
\hline $\begin{array}{ll}\text { g. } & \text { Quantity } \\
& \text { Estimating } \\
\end{array}$ & $\checkmark$ & $\checkmark$ & $\checkmark$ & & & \\
\hline h. Permitting & $\checkmark$ & $\checkmark$ & $\checkmark$ & & & \\
\hline i. Health and Safety & $\checkmark$ & $\checkmark$ & $\checkmark$ & & & \\
\hline $\begin{array}{ll}\text { j. } & \text { Application } \\
& \text { Programming } \\
\end{array}$ & $\checkmark$ & $\checkmark$ & $\checkmark$ & & & \\
\hline k. Cost Estimating & $\checkmark$ & $\checkmark$ & $\checkmark$ & & & \\
\hline 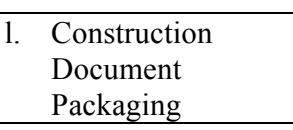 & $\checkmark$ & $\checkmark$ & $\checkmark$ & & & \\
\hline m. Contracts & $\checkmark$ & $\checkmark$ & $\checkmark$ & & & \\
\hline $\begin{array}{l}\text { n. Quality Assurance } \\
\text { and Quality } \\
\text { Control }\end{array}$ & $\checkmark$ & $\checkmark$ & $\checkmark$ & & & \\
\hline $\begin{array}{ll}\text { o. } & \text { Technical } \\
& \text { Documents } \\
\end{array}$ & $\checkmark$ & $\checkmark$ & $\checkmark$ & & & \\
\hline $\begin{array}{ll}\text { p. } & \begin{array}{l}\text { Specialized } \\
\text { Software }\end{array} \\
\end{array}$ & $\checkmark$ & $\checkmark$ & $\checkmark$ & & & \\
\hline $\begin{array}{ll}\text { q. } & \text { Project } \\
& \text { Management }\end{array}$ & $\checkmark$ & $\checkmark$ & $\checkmark$ & & & \\
\hline
\end{tabular}




\section{Discussion}

Outcomes in both bodies of knowledge include a title, a brief rubric description and a follow-up explanation or commentary. In the case of the CE-BOK3, a pathway is also provided that suggests a common means of achieving the outcome. Such a pathway is not provided for the CET-BOK due to the wide range of educational and experiential options available to a Civil Engineering Technologist. While the CE-BOK3 is presumed to represent the point of entry into professional practice, typically associated with licensure, no similar point of time in a Civil Engineering Technologists career has been identified for the CET-BOK. If and when a widely accepted credentialing system is established for the Civil Engineering Technologist, the CETBOK can then be adapted to reflect a similar milestone. For the time being, the CET-BOK should be considered as applicable after some level of post-secondary education and appropriate experience. The CE-BOK2 served to inform the development of corresponding ABET criteria and it is hoped that the CE-BOK3 will lead to a reexamination of them. In a similar manner, the CET-BOK should drive a revision of ABET criteria for corresponding technology programs.

In terms of specific outcomes, there is some overlap and differences between the two bodies of knowledge. Both bodies have outcomes on mathematics, natural sciences, social sciences and humanities, in recognition of the fundamental role that this type of knowledge plays in virtually all types of post-secondary education and employment. There are differences in terms of levels of achievement and in the outcome statements and commentaries. For example, while the need for specific calculus-based mathematics that a Professional Engineer is expected to master are explicit in the CE-BOK3, no similar detail is provided in the CET-BOK. The CE-BOK3 includes outcomes on Materials Science and Critical Thinking \& Problem Solving, whereas the closest corresponding outcomes in the CET-BOK are Civil Engineering Mechanics and Problem Identification and Resolution, respectively. There is a clear effort on the part of the CET-BOK to state outcomes in a more applied manner suitable for technologist occupations. For example, the CET-BOK lists Business Acumen as one outcome, while the CE-BOK3 identifies Engineering Economics instead. While CE-BOK3 combines teamwork and leadership into a single outcome, CET-BOK keeps them separate, as did the CE-BOK2. CE-BOK3 includes separates outcomes for Professional Attitudes and Professional Responsibilities. The closest outcome for these in the CET-BOK is the outcome on Professional Growth and Responsibilities. While both bodies expect some knowledge regarding breath of areas within civil engineering, only the CE-BOK 3 requires depth within at least one such area. This is an important and deliberate difference. Some of these differences are to be expected. On the other hand, they also reflect a lack of effective coordination that is unfortunate and that should be remedied in future editions of the two bodies of knowledge.

Despite the fact that the work of the corresponding committees overlapped for much of the time, there was a lack of extensive interaction between the two groups. Perhaps more importantly, the charges to the two task committees emanated from different umbrella committees within ASCE, with insufficient coordination between the respective committee charges and workflows (CEBOK3 was directed by the Committee on Education and CET-BOK was overseen by the Committee on Advancing the Profession). There were significant differences in the makeup of the committees, with the CE-BOK3 consisting largely of academics form baccalaureate 
programs and a few practitioners, whereas the CET-BOK committee included instructors and academics from technology degree programs and practitioners in the technology field. Only the first author of this manuscript served on both committees and this was obviously insufficient to yield better coordination. The CE-BOK3 committee employed a rigorous approach based on research, scholarship and extensive stakeholder input. While the CET-BOK committee did employ these methods as well, it relied significantly on open discussions with stakeholders within and outside the committee to create a new body of knowledge that had not been defined by formal education, work experience, or credential.

Nonetheless, the two bodies of knowledge do provide information to help define the relationship between the Civil Engineering Professional and the Civil Engineering Technologist. In simple terms, while the Civil Engineering Professional is expected to exercise responsible in charge duties and have acquired sufficient knowledge and experience to handle complex engineering problems, the Civil Engineering Technologist is presumed to have adequate knowledge and experience to address well-defined problems, and more importantly, to possess specific and indepth knowledge within at least one specialty area, knowledge that may go beyond that of the Civil Engineering Professional. With this understanding in mind, the CET-BOK identifies 17 specialty outcomes that are unique to the role of the Civil Engineering Technologist. These outcomes are formulated in the cognitive domain and for the most part have assigned levels of achievement at either Comprehension (Level 2) or Application (Level 3). One of the most useful aspects of the CET-BOK is found in the list of examples provided for each specialty outcome in the Appendix of the document.

In a first for the CE-BOK, the third edition will include affective components for seven of the cognitive outcomes (Table 1b). No affective outcomes are included in the CET-BOK. It may be questioned whether a similar expansion into the affective domain is merited for CET-BOK. It is hoped that consideration will be given to this in future versions of the CET-BOK since it could easily be argued that similar competencies should also be required of the technologist.

\section{Conclusion and Recommendations}

Civil engineering is at the forefront of the engineering profession by being the first to have developed a body of knowledge for the professional engineer. It is now the first again to have developed a body of knowledge for the technologist, thus helping to delineate the role and knowledge base of both occupations and thereby assigning importance to each one in the civil engineering workforce. This effort is to be commended. Of course, knowledge, skills and attitudes continue to change in response to advances in technology and society and therefore they must be updated periodically. ASCE has decided on an 8-year cycle of revision to its CE-BOK and a similar period is recommended for revision to the CET-BOK.

It is further recommended that both bodies be revised simultaneously and in close coordination. While separate committees for each effort may make sense, both efforts should be under the direction of a single entity within ASCE, such as the Committee on Advancing the Profession, the Committee on Education, or the Raise the Bar Committee, and under the umbrella coordination of a single individual. There should be a larger number of members working on 
both committees, with frequent combined meetings. The objective should be to develop separate but integrated bodies of knowledge for the Civil Engineering Professional and the Civil Engineering Technologist. Ongoing discussions within ASCE on the role of both occupations in the workforce should prove helpful when it comes time to update each body of knowledge once again.

Regardless of how the two bodies of knowledge are updated in the future, it is important that this take place using rigorous methodologies that take into account changes in the breath and depth of civil engineering knowledge. The widest possible input should be sought from stakeholders within the academic, practicing and government civil engineering communities. There is hardly a more significant set of documents to define and defend the civil engineering profession in a changing world.

\section{References}

[1] S. Lester, "On professions and being a professional," Stan Lester Developments, Taonton, UK, devmts.org.uk, 2015.

[2] E. Hoyle and P. D. John, Professional Knowledge and Professional Practice, London, UK: Cassell, 1995.

[3] ASCE, "Policy statement 465 - academic prerequisites for licensure and professional practice,” http://www.asce.org/issues-and-advocacy/public-policy/policy-statement-465--academic-prerequisites-for-licensure-and-professional-practice/, Reston, VA: American Society of Civil Engineers.

[4] A. Abbott, The System of Professions: An Essay on the Division of Expert Labor. Chicago, IL: University of Chicago Press, 1988.

[5] E. Freidson, Professionalism: The Third Logic, Chicago, IL: University of Chicago Press, 2001.

[6] S. J. Ressler, "Sociology of professions: Application to the civil engineering 'Raise the Bar' initiative," ASCE Journal of Professional Issues in Engineering Education \& Practice, vol. 137, no. 3, pp. 151-161, 2011.

[7] ASCE, "Policy statement 535 - defining the civil engineering team," http://www.asce.org/issues-and-advocacy/public-policy/policy-statement-535---defining-thecivil-engineering-team/, Reston, VA: American Society of Civil Engineers.

[8] ASCE, "Civil engineering technologist body of knowledge," Reston, VA: American Society of Civil Engineers, 2017.

[9] J. Roth, "Professionalism: The sociologist's decoy," Sociology of Work and Occupations, vol. 1, pp. 6-23, 1974. 
[10] J. McKinlay and J. Arches, "Towards the proletarianization of physicians," International Journal of Health Services, vol. 18, pp. 161-195, 1985.

[11] V. Fournier, "The appeal of 'professionalism' as a disciplinary mechanism," Social Review, vol. 47, pp. 656-673, 1999.

[12] M. Saks, "Analyzing the professions: The case for the neo-Weberian approach," Comparative Sociology, vol. 9, pp. 887-915, 2010.

[13] F. Parkin, Marxism and Class Theory: A Bourgeois Critique. Landon, UK: Tavistock, 1979.

[14] M. Saks, "Defining a profession: The role of knowledge and expertise," Professions \& Professionalism, vol. 2, no. 1, pp. 1-10, 2012.

[15] B. S. Bloom, M. D. Englehart, E. J. Furst, and E. J. Krathwohl, Taxonomy of Educational Objectives, the Classification of Educational Goals, Handbook I: Cognitive Domain. New York, NY: David McKay, 1956.

[16] L. W. Anderson and D. R. Krathwohl, A Taxonomy for Learning, Teaching, and Assessing: A Revision of Bloom's Taxonomy of Educational Objectives. New York, NY: Longman, 2001.

[17] K. J. Fridley, D. B. Hains, L. Nolen, B. E. Barry, and B. L. Hartmann, "Is it time for a third edition of the civil engineering body of knowledge (BOK)?" in Proceedings of the 2017 ASEE Annual Conference \& Exposition, June 25-28, 2017, Columbus, Ohio.

[18] K. J. Fridley, D. B. Hains, B. E. Barry, K. L. Sanford Bernhardt, and L. Nolen, "The third edition of the civil engineering body of knowledge: An update and overview," in Proceedings of the 2018 ASEE Annual Conference \& Exposition, June 24-27, 2018, Salt Lake City, Utah.

[19] ASCE, "Civil engineering body of knowledge for the $21^{\text {st }}$ century: Preparing the civil engineer for the future, second edition," http://www.asce.org/civil engineering body of knowledge/ Reston, VA: American Society of Civil Engineers, 2008. 